University of Nebraska - Lincoln

DigitalCommons@University of Nebraska - Lincoln

Faculty Publications, Department of Psychology

Psychology, Department of

November 2000

\title{
GENDER DIFFERENCES IN BRAZILIAN STREET YOUTH'S FAMILY CIRCUMSTANCES AND EXPERIENCES ON THE STREET
}

\author{
Marcela Raffaelli \\ University of Nebraska-Lincoln, mraffaelli1@unl.edu \\ Silvia H. Koller \\ Universidade Federal do Rio Grande do Sul, Brazil, silvia.koller@gmail.com \\ Caroline T. Reppold \\ Universidade Federal do Rio Grande do Sul, Brazil \\ Mateus B. Kuschick \\ Universidade Federal do Rio Grande do Sul, Brazil \\ Fernanda M. B. Krum \\ Universidade Federal do Rio Grande do Sul, Brazil \\ See next page for additional authors
}

Follow this and additional works at: https://digitalcommons.unl.edu/psychfacpub

Part of the Psychiatry and Psychology Commons

Raffaelli, Marcela; Koller, Silvia H.; Reppold, Caroline T.; Kuschick, Mateus B.; Krum, Fernanda M. B. ; Bandeira, Denise R.; and Simões, Carson, "GENDER DIFFERENCES IN BRAZILIAN STREET YOUTH'S FAMILY CIRCUMSTANCES AND EXPERIENCES ON THE STREET" (2000). Faculty Publications, Department of Psychology. 96.

https://digitalcommons.unl.edu/psychfacpub/96

This Article is brought to you for free and open access by the Psychology, Department of at DigitalCommons@University of Nebraska - Lincoln. It has been accepted for inclusion in Faculty Publications, Department of Psychology by an authorized administrator of DigitalCommons@University of Nebraska - Lincoln. 


\section{Authors}

Marcela Raffaelli, Silvia H. Koller, Caroline T. Reppold, Mateus B. Kuschick, Fernanda M. B. Krum, Denise R. Bandeira, and Carson Simões 


\title{
GENDER DIFFERENCES IN BRAZILIAN STREET YOUTH'S FAMILY CIRCUMSTANCES AND EXPERIENCES ON THE STREET
}

\author{
Marcela Raffaelli, \\ Department of Psychology and Institute for Ethnic Studies, University of Nebraska-Lincoln \\ Silvia H. Koller, Caroline T. Reppold, Mateus B. Kuschick, \\ Fernanda M. B. Krum, and Denise R. Bandeira, \\ Institute de Psicologia e Centro de Estudos Psicologicos sobre Meninos e Meninas de Rua, \\ Universidade Federal do Rio Grande do Sul, Porto Alegre, RS, Brazil \\ Carson Simões, \\ Department of Psychology, University of Nebraska-Lincoln
}

\begin{abstract}
Objectives: It has been proposed that homeless street girls are more likely to be from dysfunctional families and exhibit psychological distress than homeless street boys, reflecting cultural factors that result in differential norms for male and female behavior. The current analysis examined whether male and female street youth in a mid-sized Brazilian city differed in their family circumstances and day-to-day functioning on the street.

Methods: The opportunity sample consisted of 33 male (mean age 14.3, range 10-17 years) and 33 female (mean age 14.6, range 11-18 years) street youth who participated in a sentence completion task and structured interview examining family experiences and ability to meet daily needs on the street.

Results: Consistent with the cultural hypothesis, girls described more negative family backgrounds than boys (e.g., they were more likely to have left home because of conflict or abuse, and reported more negative relationships with their parents). However, girls' functioning on the street was similar to, and in some cases more positive than, that of boys (e.g., fewer girls reported police violence and begging to earn money).

Conclusions: The few gender differences that emerged in this study offer little support for the cultural hypothesis. The findings make sense if local factors, such as services available for male and female youth and public response to street youth, are considered. It appears that street youth differ in their experiences depending on local circumstances, highlighting the need for caution in generalizing about the situation of street youth in different countries.
\end{abstract}

KEY WORDS: Homelessness, Gender, Poverty, Street youth.

This research was supported by grants to Silvia H. Koller and to students at the Universidade Federal do Rio Grande do Sul from CNPq (grant No. 520140/97-4), FAPERGS (grant No. 97/0075.0), PET/CAPES, PROPESQ/UFRGS; and by grants to Marcela Raffaelli from the University of Nebraska Research Council, Institute for Ethnic Studies, and Office on International Affairs.

Submitted September 1999; revision submitted and accepted March 2000; published November 2000. 


\section{INTRODUCTION}

The United Nations defines a street youth as "any boy or girl ... for whom the street (in the widest sense of the word, including unoccupied dwellings, wasteland, etc.) has become his or her habitual abode and/ or source of livelihood; and who is inadequately protected, supervised, or directed by responsible adults" (in Lusk, 1992, p. 294). Despite the inclusion of girls in this definition, the majority of youth found on the street and included in research studies are in fact male. In Latin America, where nearly half of the world's street youth are estimated to be found (Barker \& Knaul, 1991), researchers typically observe more boys than girls on the streets (Rizzini \& Lusk, 1995). In recent years, however, the number of girls on the streets has increased and attempts to work with female street youth are hampered by lack of knowledge about how the experiences of girls on the street differ from those of their male peers (Hutz \& Forster, 1996; Hutz \& Koller, 1997; Martins, 1996).

Gender has been identified as an important organizer of many aspects of human development. In most cultures, different roles and behaviors have historically been considered appropriate for males and females (Ferreira, 1995; Kohlberg, 1966; Rossi, 1985; Weisner, Gamier, \& Loucky, 1994; Williams \& Best, 1994). Although cultures differ in the specific behaviors that are considered acceptable for males and females, there are certain similarities that are relevant to the situation of homeless youngsters. In most of the world's cultures, women and girls are traditionally kept close to home because of child-care and family responsibilities and for their own protection, whereas men and boys are encouraged to go out of the home for recreation and to earn a living. As a result of this separation of the masculine and feminine spheres, in many cultures street girls appear to be more "out of place" than street boys (Hutz \& Forster, 1996; Menezes \& Brasil, 1998; Rosemberg, 1996).

Because the presence of girls on the streets violates cultural norms for female behavior, it has been proposed that homeless girls are more likely to be from dysfunctional families and exhibit psychological distress than their male peers (e.g., Aptekar 1994; Aptekar \& Ciano-Federoff, 1999). In this view, the presence of boys on the street is thought to reflect a deliberate survival strategy by impoverished families who socialize sons into early independence in an appropriate male context - the street. In contrast, the presence of girls on the street is thought to reflect family dysfunction which has led to a breakdown in the socialization process. Thus, although boys and girls may share the common condition of being "on the street" they may be on distinct developmental trajectories, with homeless girls being at higher risk of negative outcomes than their male peers. In a recent test of the cultural hypothesis, Aptekar and Ciano-Federoff (1999) examined gender differences in the psychological functioning and life situation of a Kenyan sample of 42 street boys and 19 street girls. Statistically significant differences emerged on only one of four measures of psychological well-being, but based on ethnographic analyses the authors concluded that boys showed more positive functioning than girls. Additional research on this topic is scarce; two recent investigations of street youth in other parts of Africa do not explicitly discuss gender differences (Matchinda, 1999; Swart-Kruger \& Donald, 1996). Therefore, it is impossible to know whether similar gender-related patterns exist in other populations of street youth. The current paper builds on prior research by examining gender differences in the experiences of Brazilian homeless girls and boys prior to leaving home and on the street.

One issue addressed in this paper is whether male and female street youth differ in their family backgrounds. In Latin America, the presence of children and adolescents working and/or living on the streets is typically attributed to structural factors like high birth rates, urban-to-rural migration, economic stagnation, unequal distribution of wealth and lack of government welfare programs (e.g.. Barker \& Knaul, 1991; Carrizosa \& Poertner, 1992; Lusk, 1989; Peralta, 1992). However, given the large number of impoverished families in Latin America, it is unlikely that poverty alone can explain why some youngsters leave home to live on the street (for a thoughtful discussion of this issue, see Hecht, 1998). In a review of 
studies conducted in Latin America, Raffaelli (1997) concluded that the families of homeless street youth were more troubled than those of impoverished youngsters working on the street but living at home. For example, more homeless than working youth experienced rural-to-urban migration, parental death or absence, and physical abuse prior to leaving home. This review suggests that family disruption may be an important factor in the street youth phenomenon. However, because most studies did not report findings separately for males and females, gender differences were not examined in this review.

Several empirical studies have examined gender differences in the experiences of Latin American street youth. One study that included 200 homeless street youth aged 9 to 18 (25\% female) in Belo Horizonte, Brazil, revealed that homeless boys and girls did not differ in their family situation (e.g., parental death or absence, family contact) (Campos et al., 1994). Similarly, two small-scale studies conducted in another Brazilian city reported no gender differences in why children were on the street, the activities they pursued in street settings (Silva et al., 1998) or their social support networks (Brito, 1999). The current analysis extends prior research by examining gender differences in a range of family variables, including subjective aspects of family relationships.

A second issue addressed in this paper is whether boys and girls show differential adjustment to the street. Specifically, we examine whether boys and girls differ in how well they are able to meet their needs on the street. Given that these youngsters have left home (whether by design or involuntarily), what impact does street life have on their well-being? Again, little is known about this topic. In the process of conducting a census of street youth in Sao Paulo, Rosemberg (1996) observed that the activities of male and female street youth differed, with males playing and working more than females, and females begging more than males. This study offers anecdotal support for the notion that male youth are better able to adapt to street life. In contrast, Campos and colleagues (1994) reported that homeless girls were less likely to go hungry than boys, and more likely to have someone who would protect them, help them if they were hurt, and give them a place to sleep. In an effort to expand the knowledge base about how girls and boys fare on the streets, the current study examined gender differences in youngsters' ability to meet an array of daily needs.

Prior research on gender differences in the experiences of street youth has been limited and does not permit a critical evaluation of the cultural hypothesis, which posits that homeless girls are from more dysfunctional families and experience higher levels of psychological distress than homeless boys. In an attempt to learn more about the family backgrounds and life situations of homeless street girls, we explore gender differences in a sample of homeless Brazilian children and adolescents. Drawing on both qualitative and quantitative data, we examine whether homeless boys and girls differ in their family situation and in their ability to meet basic needs on the street.

\section{METHOD}

\section{Procedures}

The study was conducted in Porto Alegre, a mid-sized city (population 1.5 million) in Southern Brazil. Following procedures approved by Institutional Review Boards at the co-Investigators' home universities, interviewers approached potential respondents in institutional settings (e.g., shelters, open houses providing meals and recreational activities), explained the study, and invited them to participate in a two-part interview. The first part of the interview consisted of a sentence completion task, and the second part of a semi-structured interview. This type of non-random sampling is commonly used in research with homeless children, who are rarely found in contexts that permit random sampling (Matchinda, 1999). 


\section{Participants}

A total of 78 youths agreed to participate in the study; nine did not complete the entire interview and of the 69 who completed the study, two boys and one girl with no living nuclear or extended family members were excluded from the current analyses. The decision to exclude these three youngsters was made because many of the study questions dealing with family relations were not applicable to them, resulting in high levels of missing data. Therefore, the sample for the current analysis consisted of 33 male (mean age 14.3, range 10-17 years) and 33 female (mean age 14.6, range 11-18 years) street youth. One third $(33 \%)$ of these respondents were White; the majority were Black $(42 \%)$ or of mixed race $(24 \%)$.

\section{Measures}

Sentence Completion Task. Participants completed the Sentence Completion Task for Street Children and Adolescents, developed by the authors for the current study. Drawing on prior research utilizing sentence completion tasks (e.g., Cunha, Freitas, \& Raymundo, 1993), a pool of 33 potential sentence stems was developed and pilot-tested to identify 24 items assessing different domains (e.g., street life, family, future expectations). The final selection of sentence stems was based on whether the items were understandable and not redundant with other items; items that were ambiguous or resulted in similar responses to other stems were excluded.

This paper focuses on three stems dealing with different aspects of family life ('I wish my family ...;" "When I was little, my family ...;" "My family treats me like ...") and six stems dealing with the child's feelings about each parent ('I think my father/mother . . .;" "I wish my father/mother . . .;" "My father/ mother and I. .."). The sentence completion task was presented as a game. Respondents were told that the interviewer would read some unfinished sentences and that they should "finish the sentences with the first thing you think of." These instructions ensured that answers were as spontaneous as possible. The sentence completion task was very successful in eliciting responses. Interviewers reported that youngsters became readily engaged in the task, and levels of missing or uncodable responses were low. Inductively-derived content coding schemes were developed for responses to each sentence stem. Responses were classified by two coders working independently and discrepancies between coders were resolved by discussion.

Structured interview. The interview assessed various aspects of youngsters' experiences including family experiences and ability to meet daily needs on the street.

\section{Analysis Plan}

Because of the small sample size and resulting limitations in power to detect significant differences, only descriptive analyses are presented.

\section{RESULTS}

\section{Family Situation and Relationships}

Three aspects of family experiences were examined: reasons for leaving home, current family relations (structured interview), and subjective aspects of parent-child and family relationships (sentence completion task).

Reasons for leaving home. The most common reasons given for leaving home was to escape conflict or abuse, with more girls than boys giving each of these reasons (see Figure 1; because youth were allowed 


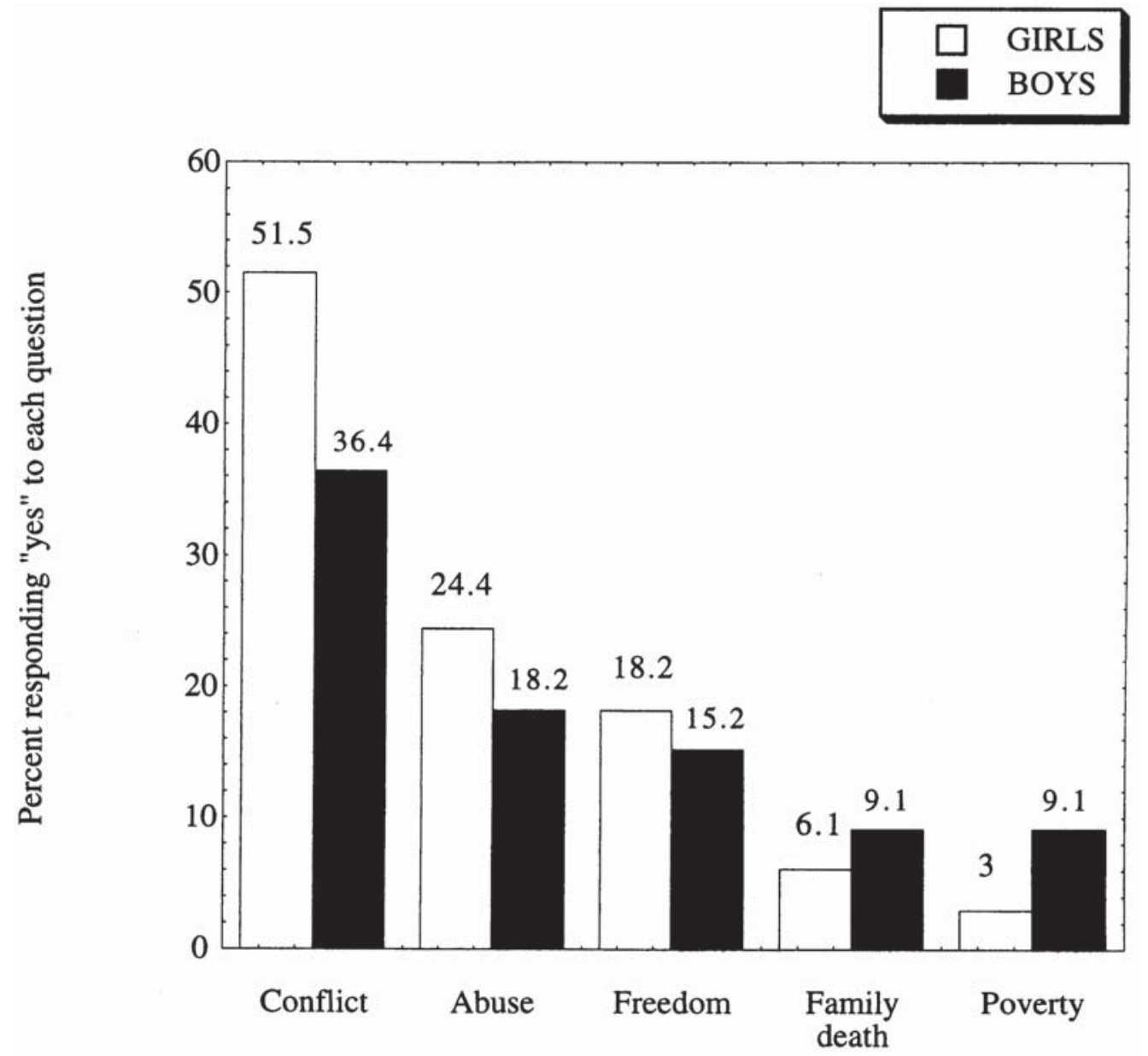

Figure 1. Reasons for leaving home.

to give up to two responses, percents do not add up to 100). Under one fifth of all respondents $(n=11)$ said they had left to seek freedom, and only five youngsters said that death in the family was a precipitant for leaving home. Additional analyses (not shown) revealed that the majority of the sample (69.7\%) had two living parents; three (4.5\%) had lost both parents, three (4.5\%) their mother, and $14(21.2 \%)$ their father. Very few of the respondents (three boys and one girl) said they had left home because of poverty.

Current family contact. As shown in Figure 2, the majority of both girls and boys had nuclear or extended family members living in the same city. However, more girls than boys said that their families had news of them and that they had visited their family home in the last month. About one fifth of girls and boys reported receiving money from family members.

Subjective aspects of family relations. The distribution of responses to two of the sentence stems dealing with parents are presented in Table 1 (responses to the third stem, "I think my father/ mother," were similar in valence to the sentence stem, "My father/mother and I," and are not presented). In response to the stems "my father/mother and I..." more of the boys than girls gave a positive response (e.g., "are happy" "are friends" "get along well") and fewer a negative response (e.g., "fight a lot," "don't get along").

In response to the sentence stems "I wish my father/mother . . ." gender differences emerged for fathers but not mothers (Table 1). Over two thirds of the girls reported wishing their father would change in some way (most commonly in how he treated the respondent or the rest of the family). 


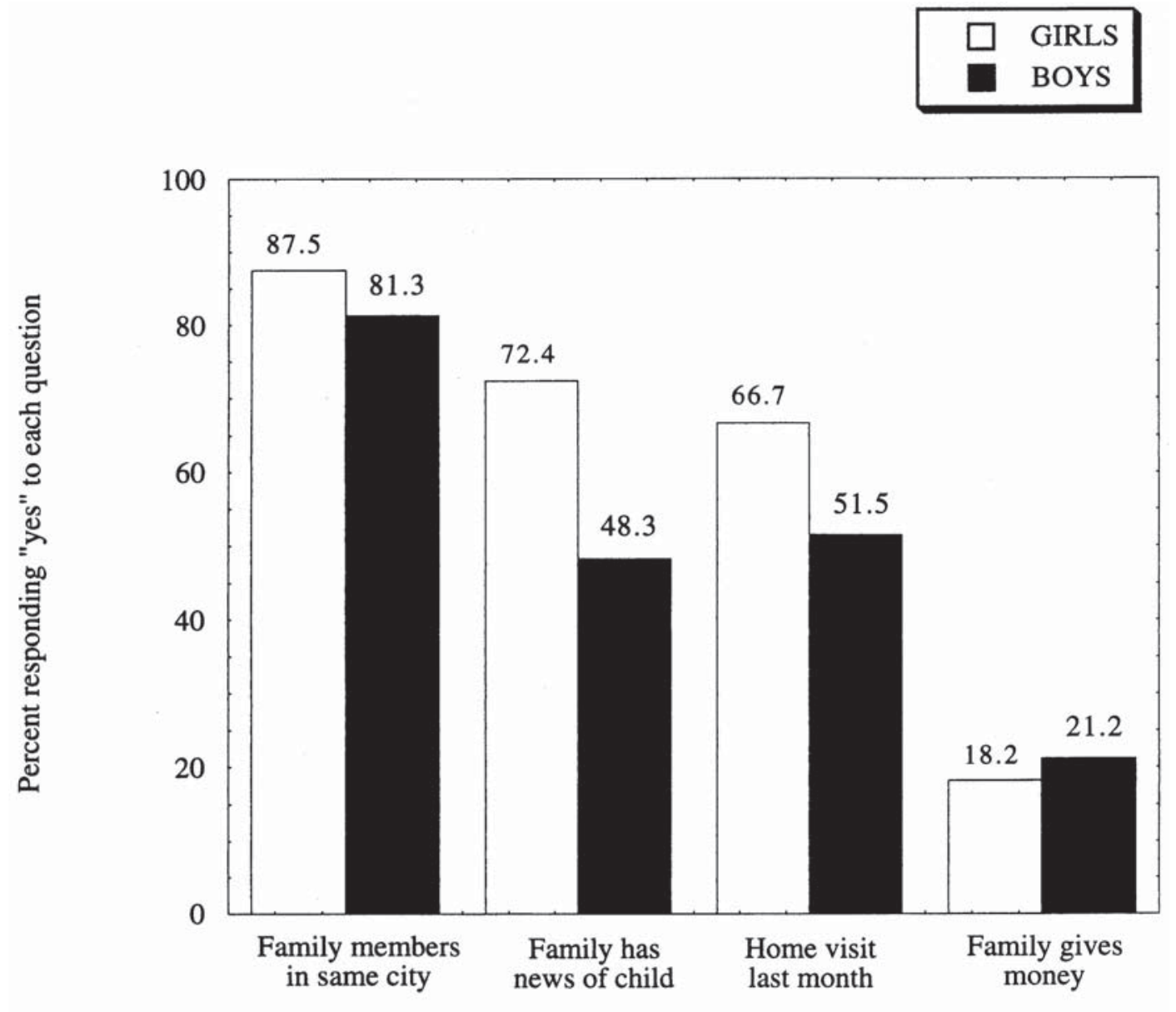

Figure 2 . Current tamily relations.

In contrast, nearly a third of the boys said they wished their father was alive or with them, and $16 \%$ said they wished their father had a better life (the latter wish was not expressed by any of the girls).

Table 2 displays responses to the three sentence stems dealing with family. No gender differences were

Table 1. Gender Differences in Responses to Sentence Stems Dealing with Parents (\% Giving Each Response)

\begin{tabular}{|c|c|c|c|c|}
\hline & \multicolumn{2}{|c|}{ "My father and I ..." } & \multicolumn{2}{|c|}{ "My mother and I ..." } \\
\hline & Girls & Boys & Girls & Boys \\
\hline Positive Relationship & 38.7 & 64.5 & 48.4 & 67.9 \\
\hline Negative Relationship & 35.5 & 12.9 & 48.4 & 25.0 \\
\hline Life Events/Changes & 6.5 & 9.7 & 0 & 7.1 \\
\hline \multirow[t]{3}{*}{ Dead/Unknown } & 19.4 & 12.9 & 3.2 & 0 \\
\hline & \multicolumn{2}{|c|}{ "I wish my father..." } & \multicolumn{2}{|c|}{ "I wish my mother..." } \\
\hline & Girls & Boys & Girls & Boys \\
\hline Change/Be Different & 68.8 & 43.8 & 58.1 & 51.7 \\
\hline Were Alive/With $\mathrm{Me}$ & 21.9 & 31.3 & 16.1 & 17.2 \\
\hline Better Life & 0 & 15.6 & 22.6 & 20.7 \\
\hline Negative or No Wish & 9.4 & 9.4 & 3.2 & 10.3 \\
\hline
\end{tabular}


Table 2. Gender Differences in Responses to Sentence Stems Dealing with Family (\% Giving Each Response)

\begin{tabular}{|c|c|c|c|}
\hline & Girls $(n=33)$ & Boys $(n=33)$ & All $(n=66)$ \\
\hline \multicolumn{4}{|c|}{ "My Family Treats Me Like ..." } \\
\hline Neutral & 10.0 & 20.0 & 15.0 \\
\hline Positive & 30.0 & 36.7 & 33.3 \\
\hline Mixed & 10.0 & 3.3 & 6.7 \\
\hline Negative & 46.7 & 33.3 & 40.0 \\
\hline No contact & 3.3 & 6.7 & 5.0 \\
\hline \multicolumn{4}{|c|}{ "When I was Little, My Family ..." } \\
\hline Positive aspects/treatment & 36.6 & 46.9 & 42.0 \\
\hline Negative aspects/treatment & 20.0 & 15.6 & 17.7 \\
\hline Was united/better & 30.0 & 25.0 & 27.5 \\
\hline Other & 13.3 & 12.5 & 12.8 \\
\hline \multicolumn{4}{|l|}{ "I Wish My Family..." } \\
\hline Was united/together & 42.4 & 42.0 & 42.2 \\
\hline Was different & 48.5 & 51.6 & 50.0 \\
\hline Other & 9.0 & 6.5 & 7.9 \\
\hline
\end{tabular}

observed in how youngsters responded to these stems. Two fifths of the youngsters completed the stem "My family treats me like ..." with a negative response (e.g., "they had never seen me;" "I didn't exist"), a third gave positive responses (e.g., "a child;" "they give me everything I want"), and the remainder gave neutral or mixed responses. When asked to finish the stem "When I was little, my family ..." over two fifths of the sample described positive aspects of the relationship, over a quarter made reference to the family being together or better in some way (e.g., "gave me more love"), under a fifth gave a negative response (typically fighting or violence toward the child). Finally, when asked to complete the stem "I wish my family ..." half of the respondents voiced a desire for change (e.g., happiness, health) and two fifths wished for their family to be reunited.

\section{Ability to Meet Basic Needs on the Street}

During the interview, respondents answered a set of questions about where they typically slept, experiences on the street, and social networks. More girls than boys said they slept in institutions (63.6\% vs. $48.5 \%)$, and fewer girls than boys slept on the street (30.3\% vs. 51.5\%). A number of gender-related differences were seen in responses to items dealing with daily survival. As shown in Figure 3, boys were more likely than girls to report experiencing police violence, begging, going hungry, and stealing. No gender differences in social networks emerged; nearly three quarters of both boys and girls said they had someone to help them and nearly two thirds were attending school.

\section{DISCUSSION}

Scholars have proposed that male and female street children and adolescents may experience differential developmental trajectories that reflect cultural norms regarding gender-appropriate behavior. According to the cultural hypothesis (Aptekar, 1994; Aptekar \& Ciano-Federoff, 1999), impoverished families encourage their sons to take to the streets at an early age in order to begin the process of becoming financially independent. In contrast, the presence of girls on the street is thought to reflect a breakdown of the normal socialization process due to family dysfunction. In this view, homeless boys are experiencing appropriate socialization but homeless girls are on an atypical developmental pathway that puts them at risk of psychological distress and maladjustment. 


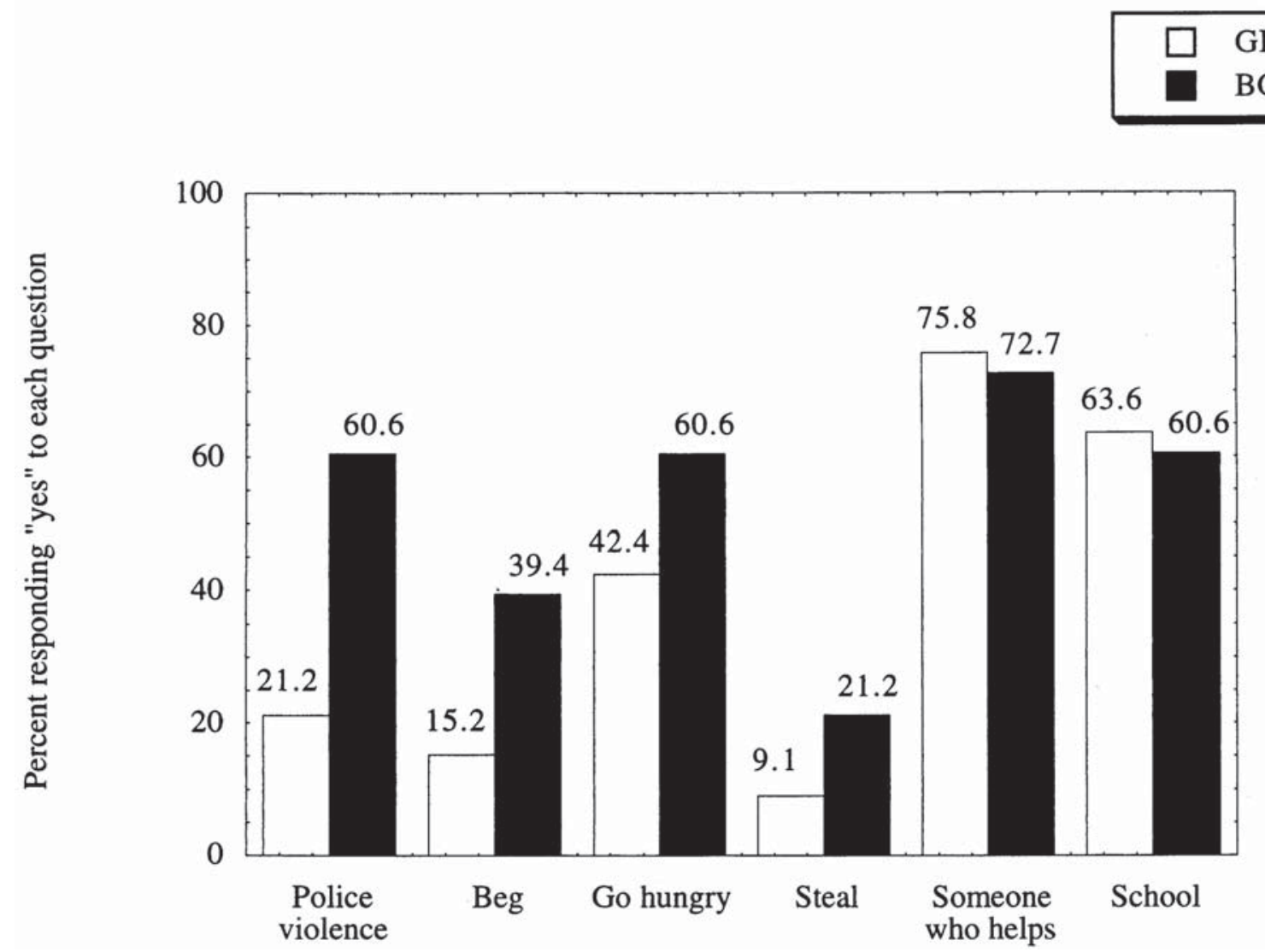

Figure 3. Ability to meet basic needs.

The goal of our paper was to evaluate the cultural hypothesis by exploring gender differences in a sample of homeless Brazilian youth, focusing in particular on their family circumstances and ability to meet basic needs on the street. Boys and girls did not differ on most of the variables examined in the current study, suggesting that their experiences both before and after leaving home have much in common.

Despite the overall lack of differences, some family variables differed for males and females in ways predicted by the cultural hypothesis. Reasons for leaving home reported by these adolescents echo those given by homeless children and adolescents in South Africa (Swart-Kruger \& Donald, 1996), Cameroon (Matchinda, 1999), Colombia (Tyier, Tyier, Echeverry, \& Zea, 1991), Mexico (Peralta, 1992), and other Brazilian cities (Carpena, 1999; Martins, 1996) (for reviews see Raffaelli, 1997; Raffaelli et al., in press; Rizzini \& Lusk, 1995). However, the current examination of gender differences revealed that girls were more likely than boys to leave home because of conflict or abuse and report negative relationships with parents. These findings provide tentative support for the view that the family situation must be particularly negative for girls to overcome cultural resistance to leaving home. Further research (or examination of gender differences in existing datasets that include both male and female respondents) is needed to clarify the family backgrounds of boys and girls on the street.

Although the girls in the current study did describe somewhat more negative family backgrounds than their male peers, girls did not appear to have a more difficult time on the street than boys. In fact, the pattern of gender differences in meeting basic needs suggests that some girls were better off than boys. Girls in our sample were less likely than their male peers to say they begged, experienced police violence, went hungry, slept on the street, or stole. Thus, it appears that girls were better able than boys to gain ac- 
cess to resources and avoid negative attention from the police and other authorities. Similarly, homeless girls in a different Brazilian city described more social resources than homeless boys (Campos et al., 1994). These findings do not support Aptekar and Ciano-Federoff's (1999) contention that homeless girls are more distressed than homeless boys, although it should be noted that the current study did not involve clinical assessments of psychological functioning.

Taken as a whole, findings from the current study offer only partial support for the cultural hypothesis as proposed by Aptekar and Ciano-Federoff (1999). Homeless street girls may come from more dysfunctional families than boys, but they may not be worse off in terms of meeting basic needs. This apparently contradictory pattern of results makes sense if the local context is taken into account. In Kenya, where the cultural hypothesis was originally tested, there are few institutions serving homeless youth, who must therefore survive on their own - a challenge that boys may be better able to confront, given gender norms within the culture (Aptekar \& Ciano-Federoff, 1999). In contrast, homeless youngsters in most Brazilian cities can turn to a variety of governmental and non-governmental agencies for assistance (Hecht, 1998). Therefore, although Brazilian homeless girls have violated cultural norms for appropriate female behavior by leaving home, their ability to obtain alternative care may enable them to cope with the immediate demands of street life as well as their male peers. The ability of Brazilian homeless youth to cope with their situation is suggested by one study's finding that homeless youth were no more depressed than impoverished youth who lived with their families (DeSouza, Koller, Hutz, \& Forster, 1995). Of course, given the multiple challenges homeless youth confront on a daily basis (for a review, see Raffaelli, 1999), no conclusions about gender differences in long-term adaptation to the street can be drawn from the current study.

\section{LIMITATIONS AND FUTURE DIRECTIONS}

There are obvious limitations in the current study, including the nonrandom and small sample and the retrospective examination of family variables. These limitations are shared by most studies of homeless youth, and are difficult to overcome. Methodological improvements would include replicating this study in different cities and countries, obtaining a larger sample, conducting prospective longitudinal research, and obtaining concurrent data from the families of origin of street youth. Another potential limitation is that the sentence completion measure used in this study has not been used in prior research with impoverished youth, and despite its success in eliciting information, its reliability and validity has not been established. Issues of methods and measurement development remain a largely neglected area that merits attention by street youth researchers (for a discussion see Hutz \& Koller, 1999).

Despite its limitations, the current analysis sheds light on gender differences in the experiences of children and adolescents seeking their survival on city streets. More importantly perhaps, it highlights the need for caution in making generalizations about the situation of street youth in different cultures. Despite their common situation of being "on the street," youth in different countries probably differ widely in their experiences depending on local circumstances and norms regarding what behavior is seen as appropriate for individuals of different genders, ages, and social classes (Earls \& Carlson, 1999). Researchers attempting to understand the adjustment of street youth have begun to take into account the larger settings in which street youth are embedded, including not only families but also social networks on the street (Ennew, 1994), work settings (Verma, 1999), public perceptions of homeless youth (Diversi, Moraes, \& Morelli, 1999), institutions providing assistance to youth (Diversi et al., 1999; Lusk, 1989) and political movements (Macedo \& Brito, 1998). It is only by considering these multiple factors that a full understanding of the situation of street youth in any particular culture can be attained. The challeng- 
es inherent in conducting high quality research with street youth are considerable; however, researchers should persevere in their endeavors, because information about this population is urgently needed to expand our basic understanding of development under stress and to inform interventions aimed at helping impoverished youth around the world.

\section{REFERENCES}

Aptekar, L. (1994). Street children in the developing world: A review of their condition. Cross-Cultural Research, 28, 195224.

Aptekar, L., \& Ciano-Federoff, L. M. (1999). Street children in Nairobi: Gender differences in mental health. In M. Raffaelli \& R. Larson (Eds.), Homeless and working youth around the world: Exploring developmental issues. New Directions for Child and Adolescent Development, 85, 35-46. San Francisco, CA: Jossey-Bass.

Barker, G., \& Knaul, F. (1991). Exploited entrepreneurs: Street and working children in developing countries (Working Paper No. 1). New York: Childhope-USA, Inc.

Brito, R.C. (1999). Uso de drogas entre meninos e meninas em situacao de rua: Subsidies para uma intervencao comunitaria [Use of drugs among boys and girls in street situations: Information for a community intervention]. Unpublished master's thesis, Universidade Federal do Rio Grande do Sul. Porto Alegre, RS, Brazil.

Campos, R., Raffaelli, M., Ude, W., Greco, M., Ruff, A., Rolf, J., Antunes, C. M., Halsey, N., \& Greco, D. (1994). Social networks and daily activities of street youth in Belo Horizonte, Brazil. Child Development, 65, 319-330.

Carpena, M. E. F. (1999). Familias de crianças em situação de rua: Locus de controle, e expectativas de vida [Families of children in street situations: Locus of control and life expectations]. Unpublished master's thesis, Universidade Federal do Rio Grande do Sul. Porto Alegre, RS, Brazil.

Carrizosa, S. O., \& Poertner, J. (1992). Latin American street children: Problem, programmes and critique. International Social Work, 35, 405-413.

Cunha, J. A., Freitas, N. K., \& Raymundo, M. G. (1993). Psicodiagnóstico-R (4th ed.). Porto Alegre, Brazil: Artes Médicas.

DeSouza, E., Koller, S. H., Hutz, C. S., \& Forster, L. M. (1995). Preventing depression among Brazilian street children. Interamerican Journal of Psychology, 29, 261-265.

Diversi, M., Moraes, N., \& Morelli, M. (1999). Daily reality on the streets of Campinas, Brazil. In M. Raffaelli \& R. Larson (Eds.), Homeless and working youth around the world: Exploring developmental issues. New Directions for Child and Adolescent Development, 85, 19-34. San Francisco, CA: Jossey-Bass.

Earls, F., \& Carlson, M. (1999). Children at the margins of society: Research and practice. In M. Raffaelli \& R. Larson (Eds.), Homeless and working youth around the world: Exploring developmental issues. New Directions for Child and Adolescent Development, 85, 71-82. San Francisco, CA: Jossey-Bass.

Ennew, J. (1994). Parentless friends: A cross-cultural examination of networks among street children and street youth. In F. Nestman \& K. Hurrelman (Eds.), Social networks and social support in childhood and adolescence (pp. 409-426). London: de Gruyter.

Ferreira, M. C. (1995). Masculinidade, feminilidade e ajustamento [Masculinity, femininity, and adjustment]. Psicologia Reflexão e Crítica, 8, 205-224.

Hecht, T. (1998). At home in the street: Street children of Northeast Brazil. New York: Cambridge University Press.

Hutz, C., \& Forster, L. M. K. (1996). Comportamentos e atitudes sexuais de crianças de rua [Sexual behavior and attitudes of street youth]. Psicologia Reflexão e Crítica, 9, 209-229.

Hutz, C. S., \& Koller, S. H. (1997). Questões sobre o desenvolvimento de crianças em situação de rua [Questions about the development of children in street situations]. Estudos de Psicologia, 2, 175-197.

Hutz, C. S., \& Koller, S. H. (1999). Methodological and ethical issues in research with street children. In M. Raffaelli \& R. Larson (Eds.), Homeless and working youth around the world: Exploring developmental issues. New Directions for Child and Adolescent Development, 85, 59-70. San Francisco, CA: Jossey-Bass.

Kohlberg, L. (1966). A cognitive-developmental analysis of children's sex-role concepts and attitudes. In E. Maccoby (Ed.), The development of sex differences (pp. 82-173). Stanford, CA: Stanford University Press.

Lusk, M. W. (1989). Street children programs in Latin America. Journal of Sociology and Social Welfare, 16, 55-77.

Lusk, M. W. (1992). Street children of Rio de Janeiro. International Social Work, 35, 293-305.

Macêdo, M. J., \& Brito, S. M. 0. (1998). A luta pela cidadania dos meninos do Movimento Nacional de Meninos e Meninas de Rua: Uma ideologia reconstrutora [The fight for citizenship of boys from the National Movement of Street Boys and Girls: A reconstructive ideology]. Psicologia Reflexão e Crítica, 11, 511-522. 
Martins, R. A. (1996). Censo de crianças e adolescentes em situação de rua em São José do Rio Preto. [Census of children and adolescents in street situations in Sao Jose do Rio Preto]. Psicologia Reflexão e Crítica, 9, 101-122

Matchinda, B. (1999). The impact of home background on the decision of children to run away: The case of Yaounde city street children in Cameroon. Child Abuse \& Neglect, 23, 245-255.

Menezes, D. M. A., \& Brasil, K. C. T. (1998). Dimensões psíquicas e sociais da criança e do adolescente em situação de rua [Psychic and social dimensions of children and adolescents in street situations]. Psicologia Reflexão e Crítica, 11, 327344.

Peralta, F. (1992). Children of the streets of Mexico. Children and Youth Services Review, 14, 347-362.

Raffaelli, M. (1999). Homeless and working street youth in Latin America: A developmental review. Interamerican Journal of Psychology, 33(2).

Raffaelli, M. (1997). The family situation of street youth in Latin America: A cross-national review. International Social Work, 40, 89-100.

Raffaelli, M., Koller, S. H., Reppold, C. T., Kuschick, M. B., Krum, F. M. B., \& Bandeira, D. R. (in press). How do Brazilian street youth experience "the street?" Childhood: A Global Journal of Child Research.

Rizzini, I., \& Lusk, M. W. (1995). Children in the streets: Latin America's lost generation. Children and Youth Services Review, 17, 391-400.

Rosemberg, F. (1996). Estimativa sobre crianças e adolescentes em situação de rua: Procedimentos de uma pesquisa [Estimates of children and adolescents in street situations: Results of a study]. Psicologia Reflexão e Crítica, 9, $21-58$.

Rossi, A. (1985). Gender and the life course. New York: Aldine.

Silva, A. S., Reppold, C. T., Santos, C. L., Prade, L. T., Silva, M. R., Alves, P. B., \& Koller, S. H. (1998). Crianças em situação de rua de Porto Alegre: Um estudo descritivo [Children in street situations in Porto Alegre: A descriptive study]. Psicologia Reflexão e Crítica, 11, 441-447.

Swart-Kruger, J., \& Donald, D. (1996). Crianças das ruas da África do Sul [Street children in South Africa]. Psicologia Reflexão e Crítica, 9, 59-82.

Tyler, F. B., Tyler, S. L., Echeverry, J. J., \& Zea, M. C. (1991). Making it on the streets in Bogota: A psychosocial study of street youth. Genetic, Social, and General Psychology, 117, 395-415.

Verma, S. (1999). Socialization for survival: Developmental issues among working street children in India. In M. Raffaelli \& R. Larson (Eds.), Homeless and working youth around the world: Exploring developmental issues. New Directions for Child and Adolescent Development, 85, 5-18. San Francisco, CA: Jossey-Bass.

Weisner, T. S., Gamier, H., \& Loucky, J. (1994). Domestic tasks, gender egalitarian values and children's gender typing in conventional and nonconventional families. Sex Roles: A Journal of Research, 30, 23-32.

Williams, J. E., \& Best, D. L. (1994). Cross-cultural views of women and men. In W. J. Lonner \& R. S. Malpass (Eds.), Psychology and culture (pp. 191-196). Boston: Allyn \& Bacon. 